\section{Seedfall studies in red spruce}

\section{G. R. POWELL}

Faculty of Forestry

University of New Brunswick

Fredericton, N.B.

\begin{abstract}
Seedfall from the 1966 cone crop in a 75 -year-old red spruce (Picea rubens Sarg.) stand in central New Brunswick was monitored with traps. The seedfall per hectare over a 12 month period was 54.8 million, weighing $146 \mathrm{~kg}$ and averaged $55 \%$ soundness. About $76 \%$ of the seed fell in the fall. This seed had a higher percentage soundness than that falling later. Fall also contained all the insect-filled seeds collected, but these constituted only $1.5 \%$ of the total seedfall. The fall of pollen cones associated with the seed crop weighed $152 \mathrm{~kg} / \mathrm{ha}$. The seedfall was higher than that reported for other North American spruce species. Inferences for biomass and litterfall studies, and for natural and artificial regeneration are briefly discussed.
\end{abstract}

\section{Introduction}

An adequate supply of good quality seed is of paramount importance to the growing reforestation program in eastern Canada. At the same time, reliance on natural regeneration for many new stands is likely to continue for decades. In the past, emphasis has been placed on means to ensure a reasonable spruce component in regeneration of former spruce-fir stands. However, few data are available on seed production of the species involved and thus little is known of this vital part of the regeneration cycle.

It is well known that seed quality is poor in medium or light seed years and thus that seed collection should be concentrated in heavy seed years. In such a year, sufficient seed must be procured for the reforestation needs for the species, by seed zones, until the likely occurrence of the next heavy seed year. Similarly, if natural regeneration is to be relied upon, maximum use should be made of heavy seed years whenever cutting programs can be planned or adjusted to take advantage of them.

Foresters involved with reforestation in New Brunswick talk wistfully of the 1966 seed year, which was the last widespread, heavy seed year for the native spruces-black spruce (Picea mariana (Mill.) B.S.P.), red spruce (Picea rubens Sarg.), and white spruce (Picea glauca (Moench) Voss). Virtually no cones were borne on red spruce for the
Résumé

La dissémination des graines de la récolte de 1966 d'un peuplement de 75 ans d'épinette rouge (Picea rubens Sarg.) situé dans une région centrale du Nouveau-Brunswick, a été effectuée au moyen de trappes. Ainsi, après 12 mois, la quantité de graines à l'hectare se chiffra à 54.8 millions, pesant $146 \mathrm{~kg}$ et atteignant, en moyenne, $55 \%$ de fermeté.

Environ $76 \%$ des semences tombaient l'automne et cette population présentait un pourcentage plus élevé de fermeté que celle qui se trouvait à tomber plus tard. Cette population présentait également une certaine proportion d'insectes à l'intérieur mais ceux-ci n'atteignaient que $1.5 \%$ du total de la récolte. La chute des cônes mâles accompagnant la récolte à proprement parler, pesait $152 \mathrm{~kg} / \mathrm{ha}$. La chute des graines était ainsi plus importante que ce qui est habituellement enregistré pour d'autres espèces d'épinettes de I'Amérique du Nord.

L'auteur discute brièvement des effets sur la biomasse et sur les études traitant des éléments de la litière forestière. II mentionne également quelques effets propres à la régénération naturelle et artificielle.

next 7 years, but some occurred on other spruces in some areas. Good seed years of red spruce occur at 3 to 8-year intervals, whereas those of black and white spruce are more frequent (U. S. For. Serv. 1948).

To adequately plan seed collection, handling, and storage for the good seed years which do occur, it is essential that knowledge of likely seed yield be increased. Some seed-production data have been given for white spruce (e.g. Roe 1952; Tripp and Hedlin 1956; Waldron 1965), black spruce (Howard 1970), Engelmann spruce (Picea engelmannii Parry) (Roe 1967) and Sitka spruce (Picea sitchensis (Bong.) Carr.) (Harris, 1969), but none are available for red spruce. In this paper data are reported on seedfall from a red spruce stand in central New Brunswick for the heavy 1966 seed year.

\section{Stand description and seed collection}

A red spruce stand on a moderately well drained upland sandy loam soil was selected in 1965 for long-term studies of seedfall and litterfall. The stand, located in the University of New Brunswick Forest, originated after a fire that occurred about 1880. Many of the trees had produced cones in 1964, which was a moderate seed year for the species.

Table 1. Number of trees per hectare by species and diameter classes and basal area by species

\begin{tabular}{|c|c|c|c|c|c|c|}
\hline $\begin{array}{l}\text { Dbh class } \\
(\mathbf{c m})\end{array}$ & $\begin{array}{c}\text { Red } \\
\text { spruce }\end{array}$ & $\underset{\mathrm{fir}}{\text { Balsam }}$ & $\begin{array}{c}\text { Eastern } \\
\text { white cedar }\end{array}$ & $\begin{array}{l}\text { Eastern } \\
\text { hemlock }\end{array}$ & $\begin{array}{c}\text { Red } \\
\text { maple }\end{array}$ & Total \\
\hline 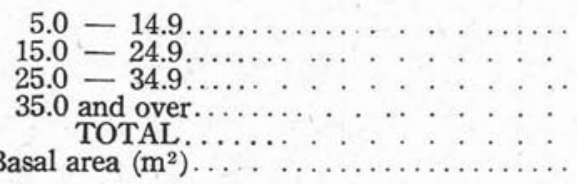 & $\begin{array}{r}526.5 \\
606.2 \\
187.5 \\
12.5 \\
1368.7 \\
38.3\end{array}$ & $\begin{array}{c}25.0 \\
50.0 \\
0 \\
0 \\
75.0 \\
1.3\end{array}$ & $\begin{array}{c}31.2 \\
12.5 \\
0 \\
0 \\
43.7 \\
0.6\end{array}$ & $\begin{array}{c}43.8 \\
6.2 \\
0 \\
0 \\
50.0 \\
0.4\end{array}$ & $\begin{array}{c}50.0 \\
31.2 \\
0 \\
0 \\
81.2 \\
1.4\end{array}$ & $\begin{array}{r}712.5 \\
706.1 \\
187.5 \\
12.5 \\
1618.6 \\
42.0\end{array}$ \\
\hline
\end{tabular}

"Acer rubrum L. 
Four, square, 0.04 ha plots were established in the stand, which contained 1619 trees/ha. Of these trees 1369 were red spruce with a basal area of $38 \mathrm{~m}^{2} /$ ha. About 200 red spruce trees/ha had $\mathrm{dbh}$ values of $25 \mathrm{~cm}$ or greater (Table 1). The mean height of the red spruce trees was $14 \mathrm{~m}$ and 44 trees/ha were taller than $20 \mathrm{~m}$. Crown lengths of the 10 tallest trees per plot averaged $7.4 \mathrm{~m}$ and crown widths $4.4 \mathrm{~m}$. Stump height ages in 1965 of these tallest trees averaged 74 years.

Seedfall was monitored with rectangular, 0.1407 $\mathrm{m}^{2}$, predation-proof litter traps. Five traps were randomly deployed on the ground in each plot in August 1965. Accumulated material in the traps was collected on the last day of each month from July to November 1966 and from May to September 1967. The collected material was air dried and components separated by hand. All seeds were counted by species, weighed, carefully dewinged and reweighed. A random 25-seed sample of each species was taken (or if less than 25 seeds occurred, all seeds were taken) from each trap collection and each seed cut. The cut seeds were categorized as sound, empty, or insect-filled.

\section{Results}

The size of the 1966 cone crop was apparent on the larger trees in the stand from the period of seed cone (megasporangiate strobilus) receptivity in early June. Spent pollen cones (microsporangiate strobili) of red spruce began to fall in June. Quantities reached a peak in August and then gradually reduced until the end of May 1967, when air-dry accumulations had averaged $15.16 \mathrm{~g} / \mathrm{m}^{2}$. Some pollen cones $\left(0.03 \mathrm{~g} / \mathrm{m}^{2}\right)$ fell later in 1967 , but since it was possible that they had been produced in 1967, they were not included.

Seedfall of red spruce, balsam fir (Abies balsamea (L.) Mill.) and eastern white cedar (Thuja occidentalis L.) began in September, and that of eastern hemlock (Tsuga canadensis (L.) Carr.) in October (Table 2). No balsam fir seeds fell after May and no eastern hemlock and eastern white cedar after June 1967. Red spruce seedfall continued throughout 1967 and into 1968. However, as in the case of pollen cones, it was impossible to be sure that some seeds were not produced in 1967, thus the red spruce seedfall from the 1966 cone crop was deemed to have been completed by the end of August 1967. It averaged 5478 seeds $/ \mathrm{m}^{2}$ of which 3030 or $55.3 \%$ were estimated to be sound (Table 2). The red spruce seedfall in the subsequent 12 months was 104 seeds $/ \mathrm{m}^{2}$ with a soundness of only $7.9 \%$. The total seedfall of the other species was 172 seeds $/ \mathrm{m}^{2}$, or $3 \%$ of the overall total. This was reduced to $2 \%$ on a sound-seed basis (Table 2).

Most of the balsam fir seed fell in September and October, when seed quality was relatively high (Table 2). The highest seedfall of eastern hemlock occurred in November, but few eastern hemlock seeds were sound (Table 2). Eastern white cedar seedfall was high in October, low in November and then relatively high overwinter, with best quality in November (Table 2).

Red spruce seedfall was heavy in September, heaviest in October and diminished thereafter. The estimated numbers of sound seeds followed essentially the same pattern (Table 2), but percentage soundness was greatest in September. It was reduced only slightly in October and November, but considerably overwinter to low values in the summer (Table 3). Of the total seedfall, $70 \%$ had fallen by the end of October, and $76 \%$ by the end of November. In sound-seed terms, $81 \%$ had fallen by the end of November (from Table 3.)

Seed-weight data (Table 3) showed a similar distribution and also reflected the decreasing soundness of the seedfall with time. The total seed weight was $14.6 \mathrm{~g} / \mathrm{m}^{2}, 80 \%$ of which was accumulated in the first 3 months. Wings, of which $3.5 \mathrm{~g} / \mathrm{m}^{2}$ fell, constituted an increasing proportion of the total as percentage soundness decreased; from September to November about $20 \%$ of the total seed weight was wings, later about $36 \%$. The weight per 1000 seeds without wings averaged $2.00 \mathrm{~g}$. It was highest $(2.30 \mathrm{~g})$ in September and dropped rapidly after November.

Of the total red spruce seedfall, $43.2 \%$ was estimated to be empty and $1.5 \%$ insect filled. This latter amounts to about 78 seeds $/ \mathrm{m}^{2}$, all of which fell in the first 3 months of seedfall.

Table 2. Total seedfall and estimated sound seedfall per square metre from the 1966 cone crop in a red spruce stand by periods from September 1966 to August 1967

\begin{tabular}{|c|c|c|c|c|c|c|c|c|}
\hline Species & $\begin{array}{l}\text { Sept. } \\
1966\end{array}$ & $\begin{array}{l}\text { Oct. } \\
1966\end{array}$ & $\begin{array}{l}\text { Nov. } \\
1966\end{array}$ & $\begin{array}{l}\text { Dec-May } \\
1966-67\end{array}$ & $\begin{array}{l}\text { Jun. } \\
1967\end{array}$ & $\begin{array}{l}\text { Jul. } \\
1967\end{array}$ & Aug. & Total \\
\hline \multicolumn{9}{|c|}{ Total number of seed } \\
\hline 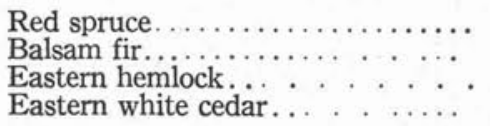 & $\begin{array}{c}1,290.4 \\
35.2 \\
0 \\
0.4\end{array}$ & $\begin{array}{r}2,566.0 \\
35.5 \\
2.5 \\
10.3\end{array}$ & $\begin{array}{r}328.3 \\
6.8 \\
3.9 \\
2.8\end{array}$ & $\begin{array}{r}1,154.0 \\
17.8 \\
7.1 \\
47.3\end{array}$ & $\begin{array}{c}94.9 \\
0 \\
0.7 \\
1.1\end{array}$ & $\begin{array}{l}23.1 \\
0 \\
0 \\
0\end{array}$ & $\begin{array}{l}21.3 \\
0 \\
0 \\
0\end{array}$ & $\begin{array}{r}5,478.0 \\
95.9 \\
14.2 \\
61.8\end{array}$ \\
\hline TOTAL $\ldots \ldots \ldots . . .$. & $1,326.0$ & $2,614.3$ & 341.8 & $1,226.2$ & 96.7 & 23.1 & 21.3 & $5,649.9$ \\
\hline \multicolumn{9}{|c|}{ Estimated number of sound seed } \\
\hline 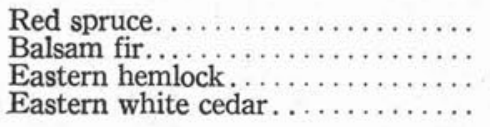 & $\begin{array}{c}815.1 \\
16.3 \\
0 \\
0\end{array}$ & $\begin{array}{r}1,444.3 \\
16.7 \\
0.7 \\
3.5\end{array}$ & $\begin{array}{r}206.1 \\
0.7 \\
0.4 \\
1.4\end{array}$ & $\begin{array}{r}537.6 \\
4.3 \\
1.4 \\
19.2\end{array}$ & $\begin{array}{l}23.4 \\
0 \\
0 \\
0.4\end{array}$ & $\begin{array}{l}2.5 \\
0 \\
0 \\
0\end{array}$ & $\begin{array}{l}1.4 \\
0 \\
0 \\
0\end{array}$ & $\begin{array}{r}3,030.3 \\
38.0 \\
2.5 \\
24.5\end{array}$ \\
\hline$\ldots \cdot \cdots \cdot$ & 831.4 & $1,465.2$ & 208.6 & 562.5 & 23.8 & 2.5 & 1.4 & $3,095.3$ \\
\hline
\end{tabular}


TABLE 3. Red spruce seedfall data from the 1966 cone crop by periods from September 1966 to August 1967

\begin{tabular}{|c|c|c|c|c|c|c|c|c|}
\hline & $\begin{array}{l}\text { Sep. } \\
1966\end{array}$ & $\begin{array}{l}\text { Oct. } \\
1966\end{array}$ & $\begin{array}{l}\text { Nov. } \\
1966\end{array}$ & $\begin{array}{r}\text { Dec-May } \\
1966-67\end{array}$ & Jun. & $\begin{array}{l}\text { Jul. } \\
1967\end{array}$ & $\underset{1967}{\text { Aug. }}$ & $\begin{array}{l}\text { Whole } \\
\text { period }\end{array}$ \\
\hline 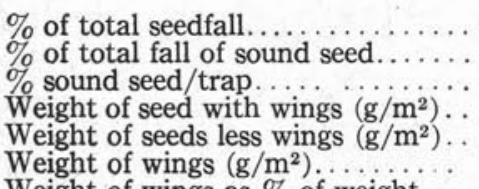 & $\begin{array}{l}23.6 \\
26.9 \\
62.0 \\
3.65 \\
2.96 \\
0.68\end{array}$ & $\begin{array}{l}46.8 \\
47.7 \\
54.0 \\
7.23 \\
5.60 \\
1.63\end{array}$ & $\begin{array}{c}6.0 \\
6.8 \\
59.0 \\
0.81 \\
0.65 \\
0.17\end{array}$ & $\begin{array}{l}21.1 \\
i 7.7 \\
46.6 \\
2.68 \\
1.75 \\
0.93\end{array}$ & $\begin{array}{c}1.7 \\
0.8 \\
24.0 \\
0.18 \\
0.10 \\
0.07\end{array}$ & $\begin{array}{l}0.4 \\
0.1 \\
6.4 \\
0.03 \\
0.02 \\
0.01\end{array}$ & $\begin{array}{l}0.4 \\
0.0 \\
6.5 \\
0.03 \\
0.02 \\
0.01\end{array}$ & $\begin{array}{l}55.3 \\
14.61 \\
11.10 \\
3.50\end{array}$ \\
\hline $\begin{array}{l}\text { Weight of wings as } \% \text { of weight } \\
\text { of seeds with wings... } \\
\text { Weight } / 1000 \text { seeds less wings }(\mathrm{g}) . .\end{array}$ & $\begin{array}{l}18.8 \\
2.30\end{array}$ & $\begin{array}{c}22.5 \\
2.18\end{array}$ & $\begin{array}{c}20.4 \\
1.97\end{array}$ & $\begin{array}{c}34.7 \\
1.52\end{array}$ & $\begin{array}{c}41.4 \\
1.08\end{array}$ & $\begin{array}{c}37.4 \\
0.78\end{array}$ & $\begin{array}{c}32.7 \\
1.05\end{array}$ & $\begin{array}{c}24.0 \\
2.00\end{array}$ \\
\hline
\end{tabular}

\section{Discussion}

The total red spruce seedfall from the 1966 cone crop amounted to $54,478,000$ seeds/ha. Of these, $30,300,000$ were estimated to be sound. The largest seedfalls (numbers/ha) reported for various North American spruces are

white spruce, $40,802,000-65 \%$ sound (Zasada and Viereck 1960);

Engelmann spruce, $8,676,000-57 \%$ sound (Roe 1967);

Sitka spruce about $10,000,000$ - about $67 \%$ (Harris 1969);

black spruce, 2,743,000 (highest annual fall in 4 years - about $40 \%$ viable (Howard 1970).

Although direct comparisons are inappropriate because of different site, stand and species characteristics, it is clear that the red spruce seedfall for the 75-year-old stand must be rated as very heavy (some of the above were rated as excellent or bumper).

The fact that this very heavy seed year occurred 2 years after a medium cone-bearing year is interesting. Red spruce cones are borne largely, but not exclusively, in terminal positions on the shoots. They thus replace vegetative buds and reduce the numbers of shoots which can elongate in a conebearing year and consequently reduce the photosynthetic capacity and the potential number of sites for cone production in the subsequent year. Tirén (1935) reported this kind of occurrence in Picea abies (L.) Karst. and estimated that, after heavy flowering, it took 2 years for the build-up of a complement of shoots equivalent to that before the heavy flowering. Tirén (1935) thus postulated that $P$. abies was unlikely to produce heavy seed years at less than 3-year intervals, and light flowering years in intervening years would tend to lengthen the period between heavy seed years. It is probable that a similar morphological (and associated physiological) impediment to heavy flowering at close intervals is operative in red spruce. The dearth of flowering during a 7-year period since 1966 supports this. However, increasing incidence since 1968 of defoliation by spruce budworm (Choristoneura fumiferana (Clem.)) in the stand under study, has also affected cone formation.

In this study $70 \%$ of the red spruce seed fell in the first 2 months, and $76 \%$ in the first 3 months. A further $21 \%$ fell overwinter, and only $2.5 \%$ during the summer months. This pattern of seedfall shows the red spruce to be similar to white (Roe
1946; Waldron 1965), Engelmann (Roe 1967) and Sitka (Harris 1969) spruces in which about $75 \%$ of the seedfall from a cone crop occurs within about 2 months of cone ripening. In contrast, Howard (1970) found that $52 \%$ of the annual seedfall of black spruce occurred from June to August. The red spruce stand studied is located in an area where introgressive hybridization occurs between red and black spruces (Morgenstern and Farrar 1964; Manley 1969). The fact that delayed seedfall did not occur suggests that the designation of the stand as a red spruce stand is warranted.

This is supported further by the seed-weight data. The seeds less wings averaged $500,000 / \mathrm{kg}$, which is above the average $(309,000)$ but well within the range given for red spruce $(220,500$ to 637,000$)$ and below the low given for black spruce $(729,000)$ (U.S. For. Serv. 1948). The value above the average for red spruce is consistent with the statement (U.S. For. Serv. 1948) that red spruce seed is heavier in the southern than in the northern part of its range, but is also relatively high because it relates to all seeds, not cleaned seeds.

It is generally found that soundness increases with the size of the seed crop. However, the soundness percentage (55) was somewhat low in comparison with those reported (57 to 67) for excellent seed years of other spruces (Zasada and Viereck 1960; Waldron 1965; Roe 1967; Harris 1969). The much greater soundness among early seedfall than later seedfall was consistent with reports for other species. As is common in heavy seed years (U.S. For. Serv. 1948; Fye and Wylie 1968), few insectcontaining seeds occurred; the great majority of non-sound seed were empty.

The heaviness of a seed crop, and associated production of other reproductive structures, has important influences in relation to biomass or litterfall studies in species showing variable and distinct seed-year periodicity. The pollen cones that fell after the 1966 flowering weighed $151.6 \mathrm{~kg} / \mathrm{ha}$. If the pollen produced by a pollen cone is assumed to weigh about half the weight of a pollen cone, as in balsam fir (Powell 1970a), then the male structures constitute a weight of about $300 \mathrm{~kg} / \mathrm{ha}$. The seeds (with wings), which fell in the 12 months following 1966-cone ripening, weighed $146 \mathrm{~kg} / \mathrm{ha}$. Red spruce seed cones from the area average 82.5 cone scales of which 49.4 are in the productive portion of the cone (cf. Tripp and Hedlin 1956). Some empty seeds and wings with undeveloped ovules are produced outside this productive portion. 
If these are released before cone-fall, then the number of scales producing winged ovules or seeds may be about 65, and the number of "seeds" released per cone, about 130 . This means that the 1966 perhectare seedfall was produced by about 421,000 cones. Red spruce seed cones in the area weigh about $2.1 \mathrm{~g}$ and thus the cone crop produced in 1966 weighed about $884 \mathrm{~kg} / \mathrm{ha}$. Male parts, seeds and cones produced by the red spruce stand in 1966 thus can be estimated to have weight about 1,330 $\mathrm{kg} / \mathrm{ha}$. This is about $40 \%$ of the mean value for total annual litterfall derived from data listed for Picea abies (the most intensively studied spruce species) by Bray and Gorham (1964). The consequences of inclusion or exclusion of heavy seed years in relatively short-term litterfall studies are obvious. Additionally, since production of large numbers of cones results in reduction in numbers of shoots, and probably lengths of shoots, as in balsam fir (Morris 1951), foliage production will decrease for one or more years and later needlefall will be affected.

Natural regeneration under red spruce-balsam fir stands is likely to be composed mostly of balsam fir until late in the stand's life (cf. Long 1947). This pattern is evident in the University of New Brunswick Forest. Twenty years ago red spruce regeneration was virtually absent but balsam fir plentiful. Now, red spruce is frequent, sometimes abundant. This is partially the result of the modified uniform shelterwood method of regeneration being used, in which most balsam fir trees are removed in the first regeneration cut (when many are becoming decadent), but also reflects the greater ability of the now older red spruce to bear seed abundantly - although infrequently. The plentiful regeneration of balsam fir can largely be attributed to seed-production differences between the species, although other factors such as spruce seeds being eaten by rodents in preference to balsam fir seeds (Abbott and Hart 1960 ) and balsam fir seedlings having an initial size advantage (Place 1955) may play a part. Balsam fir produces seeds abundantly and regularly - often biennially (Morris 1950; Powell 1970b) - from a relatively early age, while red spruce produces seeds infrequently and usually not abundantly until about the time (70 years) when many balsam fir trees are dropping out of the stands. If natural regeneration of red spruce is the objective and if rotations are to be short, forest managers must make full use of red spruce seed years whenever they occur.

As emphasis on artificial regeneration increases, and with it, the need to ensure procurement of adequate supplies of ecologically and genetically "safe" seed from seed-production stands, it becomes imperative that every heavy seed year be used to the full. This study has shown that up to 30 million sound red spruce seed could be gathered from a 1-hectare stand of 75-year-old red spruce in a very heavy seed year. Although further studies are required to determine average seed-year values, the results of this study should be of assistance in the planning and excution of seed-collection programs and in assessing requirements in terms of numbers and sizes of seed-production stands to meet the annual seed requirement.

\section{Acknowledgements}

The author is indebted to lan R. Methven for assistance in data collection and for helpful comments on the manuscript. This study was supported in part by Grant No. G-52 of the New Brunswick Research and Productivity Council.

\section{References}

Abbott, H. G. and Hart, A. C. 1960. Mice and voles prefer spruce seeds. U.S. Dep. Agric., For. Serv., Northeast. For. Exp. Sta., Sta. Pap. 153, 12 p.

Bray, J. R. and Gorham, E. 1964. Litter production in forests of the world. Adv. Ecol. Res. 2:101-157.

Fye, R. E. and Wylie, W. D. 1968. Notes on insects attacking spruce and fir cones at Black Sturgeon Lake, Ontario, 1963-4. Can. Dep. Fish. For., Bi-mo. Res. Notes 24:47-48.

Harris, A. S. 1969. Ripening and dispersal of a bumper western hemlock-Sitka spruce seed crop in southeast Alaska. U.S. For. Serv., Res. Note PNW-105. 11 p.

Howard, E. W. 1970. Dissemination and viability of seed from upland black spruce in central Newfoundland. Can. Dep. Fish. For., Bi-mo. Res. Notes 26:29.

Long, H. D. 1947. The prevention of regeneration failures of pulpwood species. Pulp and Pap. Res. Inst. Can., Woodlands Res. Index No. 27 (F-2). 6 p.

Manley, S. A. M. 1969. Genecology of red and black spruce in central New Brunswick. M.Sc.F. Thesis, Univ. New Brunswick, Federicton, N.B. 75 p.

Morgenstern, E. K. and Farrar, J. L. 1964. Introgressive hybridization in red and black spruce. Univ. Toronto, Fac. For., Tech. Rep. 4. 46 p.

Morris, R. F. 1951. The effects of flowering on the foliage production and growth of balsam fir. For. Chron. 27:40-57.

Place, I. C. M. 1955. The influence of seed-bed conditions on the regeneration of spruce and balsam fir. Can. Dep. Northern Affairs Nation. Resources, For. Bra., For. Res. Div., Bull. 117. 87 p.

Powell, G. R. 1970a. Postdormancy development and growth of microsporangiate and megasporangiate strobili of Abies balsamea. Can. J. Bot. 48:419-428.

Powell, G. R. 1970b. Some intrinsic factors affecting seed production in balsam fir. Ph.D. Thesis, Univ. Edinburgh, Edinburgh, Scotland. 522 p.

Roe, A. L. 1967. Seed dispersal in a bumper spruce seed year. U.S. For. Serv., Res. Pap. INT-39, 10 p.

Roe, E. I. 1946. Extended periods of seedfall of white spruce and balsam fir. U.S. Dep. Agric., For. Serv., Lake Sta. For. Exp. Sta., Tech. Note 2611 p.

Roe, E I. 1952. Seed production of a white spruce tree. U.S. Dep. Agric., For. Serv., Lake Sta. For. Exp. Sta., Tech. Note 373. 1 p.

Tirén, L. 1935. Om granens kottsöttning, dess periodicitet och samband med temperatur och nederbörd. Medd. Stat. Skogsf.anst. 28:413-524.

Tripp, H. A. and Hedlin, A. F. 1956. An ecological study and damage appraisal of white spruce cone insects. For. Chron. 32:400-410.

U.S. For. Serv. 1948. Woody plant seed manual. U.S. Dep. Agric., For. Serv., Misc. Publ. 654416 p.

Waldron, R. M. 1965. Cone production and seedfall in a mature white spruce stand. For. Chron. 41:314-329.

Zasada, J. C. and Viereck, L. A. 1970. White spruce cone and seed production in interior Alaska, 1957-68. U.S. For. Serv., Res. Note PNW-129. 11 p. 